\title{
Pilot-Scale Production of Washed Cottonseed Meal and Co-Products
}

\author{
Zhongqi He ${ }^{1}, \mathrm{~K}$. Thomas Klasson ${ }^{1}$, Donghai Wang ${ }^{2}$, Ningbo $\mathrm{Li}^{2}$, Hailin Zhang ${ }^{3}$, Dunhua Zhang ${ }^{4} \&$ Tom C. \\ Wedegaertner ${ }^{5}$ \\ ${ }^{1}$ Southern Regional Research Center, USDA Agricultural Research Service, USA \\ ${ }^{2}$ Department of Biological and Agricultural Engineering, Kansas State University, Manhattan, USA \\ ${ }^{3}$ Department of Plant and Soil Sciences, Oklahoma State University, Stillwater, USA \\ ${ }^{4}$ USDA-ARS, Aquatic Animal Health Research Unit, Auburn, USA \\ ${ }^{5}$ Cotton Incorporated, Cary, USA \\ Correspondence: Zhongqi He, USDA-ARS, Southern Regional Research Center, 1100 Robert E. Lee Blvd., New \\ Orleans, LA 70124, USA. Tel: 1504-2864-516. Fax: 1504- 2864-367. E-mail: Zhongqi.He@ars.usda.gov
}

Received: September 7, 2015

doi:10.5539/mas.v10n2p25
Accepted: November 25, 2015 Online Published: December 24, 2015

URL: http://dx.doi.org/10.5539/mas.v10n2p25

\begin{abstract}
Enhanced utilization of defatted cottonseed meal (CSM)-based products as biobased raw materials would increase the profitability of cotton growers and processors. In this work, a multiple-step procedure that can be used to produce water washed cottonseed meal (WCSM) and a co-product water soluble cottonseed protein $(\mathrm{CSP})$ from CSM was tested at pilot scale. Alternatively, the procedure can also be used to produce CSPw, alkali soluble protein (CSPa) and the protein extracted insoluble residue (CSIR). The chemical composition of these pilot-produced products was generally comparable to that of the corresponding laboratory-prepared products. The fiber content was higher in the pilot-produced WCSM than in laboratory-produced product mainly due to the higher fiber content in the mill-based starting meal material used in the pilot trial. The protein content in the pilot-produced CSPw was only $64.4 \%$ of the solid matter, indicating that additional rinse is needed before drying the HCl-precipitated CSPw fraction. Per the yield and composition data, it was concluded that it was feasible to produce the four products WCSM, CSPw, CSPa, and CSIR from CSM in a large scale. Thus, adoption of this procedure would provide the necessary quantities for exploring the practical utilization of these products in biomaterial industry.
\end{abstract}

Keywords: biomaterials, cottonseed, defatted meal, protein isolate, pilot production

\section{Introduction}

As a crop of fiber source for textile globally, cotton (Gossypium hirsutum L.) is produced in more than 30 countries (Campbell et al., 2014). Much of the cotton land area in the US is located in the southern and southeastern region (e .g. Georgia, Alabama, Arkansas, North Carolina, Mississippi, and Texas) (Bellaloui \& Turley, 2013; Bellaloui et al., 2015b; Tazisong et al., 2013). However, in addition to fiber, cotton crop also produce a great amount of seed biomass (Bellaloui et al., 2015a; Pettigrew \& Dowd, 2014). The residual fraction of cottonseed after oil crushing, called defatted cottonseed meal (CSM), is mainly used as soil amendment and animal feed (Broderick et al., 2013; Li et al., 2012; Wanapat et al., 2013). Thus, value added utilization of CSM products as industrial and biobased raw materials would increase the profitability of cotton growers and processors. One of the potential value-added products is wood adhesive using water washed cottonseed meal (WCSM) (He et al., 2014a, 2014b, 2014c) or cottonseed protein isolate (CSPI) (Cheng et al., 2013). CSPI is also investigated as potential bio-based materials such as bioplastics (Yue et al., 2012) and superabsorbent hydrogel (Zhang et al., 2010).

Previous work reported the laboratory (5-13 g starting material) procedures of water washing for WCSM preparation (He et al., 2014c) and sequential extraction-precipitation for obtaining water soluble cottonseed protein (CSPw), alkali soluble cottonseed protein (CSPa), and CSPI (He et al., 2013a) and their fluorescence characteristics (He et al., 2014e). Indeed, the washing step in WSCM preparation is equivalent to the first extraction step in CSPw preparation. Thus, in this work, the pilot scale [10 lb (4.54 kg) starting material] multiple-step procedure that can be used to produce CSPw and WCSM, and alternatively, CSPw, CSPa and 
alkali insoluble fraction (CSIR) (Figure 1) were practiced. In this pilot experiment, the "real world" mill-produced CSM was used as the staring material that was not always the same in chemical composition as the laboratory-produced CSM (Table 1). The purposes of the pilot work were to 1) evaluate the operational parameters for production of large quantities of cottonseed meal-based products, and 2) determine the chemical composition of the pilot produced products for quality control and the feasibility of future mill scale production of these products.

Table 1. Comparison of the major components in mill-produced (Mill-1 and Mill-2) and lab-prepared (Lab-1 and Lab-2) cottonseed meals

\begin{tabular}{|c|c|c|c|c|c|c|c|}
\hline & Moisture & Protein & Oil & $\mathrm{CF}$ & $\mathrm{ADF}$ & NDF & ADL \\
\hline & \multicolumn{7}{|c|}{ - } \\
\hline Mill-1 & 8.4 & 34.1 & 2.5 & 11.7 & 20.8 & 23.0 & 7.2 \\
\hline Mill-2 & 9.8 & 40.0 & 1.3 & 11.5 & 19.0 & 27.0 & 6.4 \\
\hline Lab-1 & 11.4 & 58.7 & 0.3 & 2.4 & 3.7 & 16.1 & 0.3 \\
\hline Lab-2 & 8.2 & $50.7^{\top}$ & $\sim 1.0^{7}$ & $3.3^{\top}$ & $5.5^{\top}$ & $11.9^{\top}$ & $1.0^{\top}$ \\
\hline
\end{tabular}

Notes. ${ }^{\dagger}$ Data from He et al. (2015). ${ }^{\ddagger}$ Data from He et al. (2014c).

\section{Materials and Methods}

\subsection{Materials}

Mill-scale produced WCM (Mill-1) was provided by Cotton, Inc. (Cary, NC, USA) and used as the starting material of the pilot work. Another batch of mill-scale produced WCM (Mill-2) was obtained from Kentwood Co-op (Kentwood, LA, USA) and used only for property comparisons (Table 1). Chemical reagents used in this work were purchased from Sigma (St. Louis, MO, USA) unless specified otherwise. Tap water was used in the pilot work. Distilled water or deionized water was used for all laboratory analysis.

\subsection{Pilot Work}

Figure 1a outlines the flow diagram of the separation procedure to obtain the four products, CSPw, WCSM, CSIR and CSPa. The starting CSM (Mill-1) was first milled to the particle size less than $0.5 \mathrm{~mm}$. The pilot work was started with mixing $10 \mathrm{lb}(4.54 \mathrm{~kg})$ of CSM with $80 \mathrm{lb}(36.3 \mathrm{~kg})$ of water for the first wash cycle, followed by a centrifuging process at $6,000 \mathrm{rpm}$ for $15 \mathrm{~min}$. The water washed fraction then went through a second wash cycle by mixing with $10 \mathrm{lb}(4.54 \mathrm{~kg})$ of tap water. After washed twice, the water washed fraction of CSM was equally divided into two parts. One part was WCSM product after appropriate treatments. Another part was used to extract CSPa with alkaline solution and the residues after the extraction was saved as CSIR. CSPw was precipitated out from the soluble fraction by adjusting $\mathrm{pH}$ to 4.0 by $1 \mathrm{M} \mathrm{HCl}$. Triplicate experiments were performed.

For comparison, in a separate procedure (Figure 1b), CSPI was prepared with $10 \mathrm{lb}$ CSM (Mill-1) as the starting material. CSPI was obtained by the procedure of $0.027 \mathrm{M} \mathrm{NaOH}$ extraction and $1 \mathrm{M} \mathrm{HCl}$ precipitation (pH 5.0) adapted from literature (Berardi et al., 1969; He et al., 2013a; Zhang et al., 2009). Duplicate experiments were performed.

\subsection{Ash and Elemental Analysis}

Ash content was determined by heating $1.0 \mathrm{~g}$ of each ground sample in a muffle furnace at $550{ }^{\circ} \mathrm{C}$ for 4 hours. The mineral content of the seed was analyzed following the digestion (Jones \& Case, 1990) in which $0.50 \mathrm{~g}$ of ground sample was digested in $10.0 \mathrm{~mL}$ of concentrated trace metal grade $\mathrm{HNO}_{3}$ for one hour in the HotBlock ${ }^{\mathrm{TM}}$ Environmental Express block digester. The sample was then heated to $115^{\circ} \mathrm{C}$ for $2 \mathrm{~h}$ and $15 \mathrm{~min}$. The concentrations of 13 elements (i. e. Al, B, Ca, Cu, Fe, K, Mg, Mn, Na, Ni, P, S, and Zn) in these digests were determined by a Spectro CirOs ICP spectrometer (Mahwah, NJ, USA) (He et al., 2013b).

\subsection{Determination of Fiber and Oil Contents}

Contents of moisture (through $105^{\circ} \mathrm{C}$ oven drying) and crude fiber (through acid and alkaline digestion) were analyzed by Ward Laboratories (Kearney, NE, USA). Acid detergent fiber (ADF), neutral detergent fiber (NDF) and acid detergent lignin (ADL) were determined using the filter bag methods with an Ankom Fiber Analyzer (Ankom Technology, Macedon, NY) (He et al., 2014f). Contents of cellulose and hemicellulose were calculated per the differences between ADF and ADL, and that between NDF and ADF, respectively(He et al., 2015; Wolfrum et al., 2009). 
(a). Pilot scale production of WCSM and coproducts

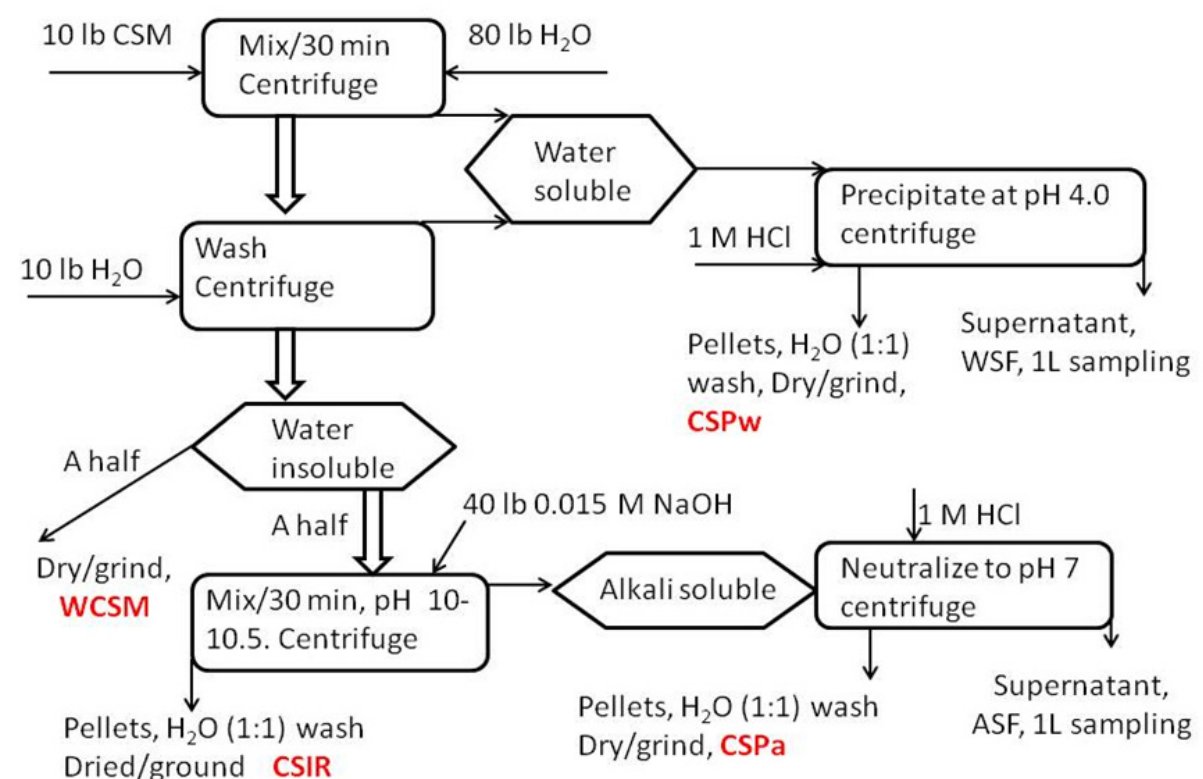

(b). Pilot scale production of CSPI
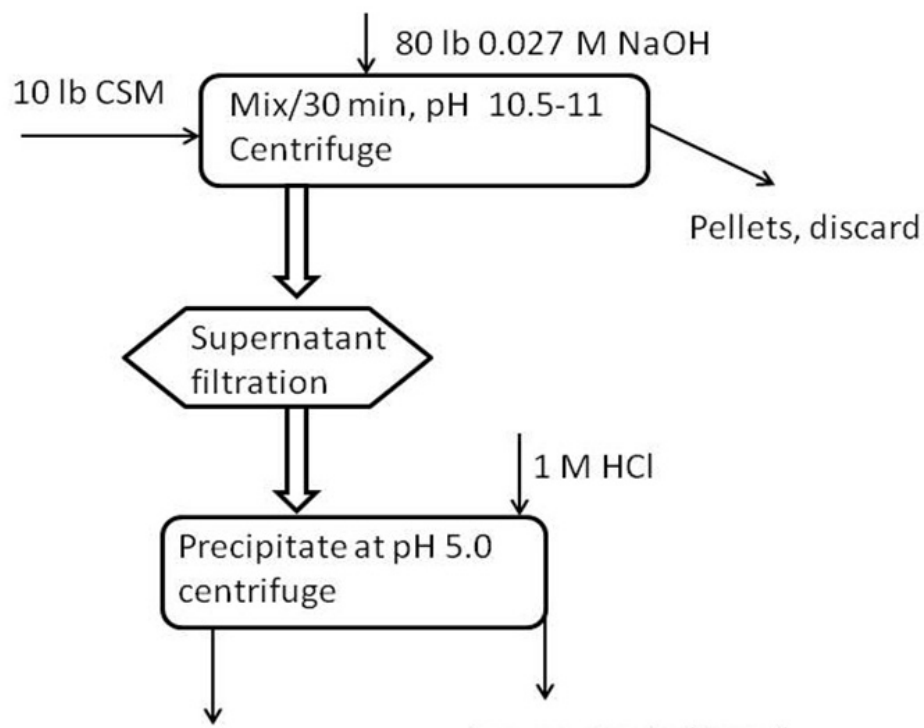

Pellets, $\mathrm{H}_{2} \mathrm{O}(1: 1)$ wash $\quad$ Supernatant, discard Dry/grind CSPI

Figure 1. Flow charts of pilot trials. (a) Pilot scale production of washed cottonseed meal product (WCSM) and co-product water soluble cottonseed protein $(\mathrm{CSPw})$, alternative products alkali soluble cottonseed protein (CSPa) and alkali insoluble cottonseed meal residual fraction (CSIR) per $10 \mathrm{lb}(4.54 \mathrm{~kg})$ of the staring material cottonseed meal (CSM). Water (WSF) and alkali (ASF) soluble residual supernatant fractions were not collected.

(b) Comparative work for production of cottonseed protein isolate (CSPI)

Total oil content was determined using Soxhlet extraction with the Tecator Soxtec System HT 1043 (Foss, Eden Prairie, MN, USA) using boiling and condensing temperatures of $110{ }^{\circ} \mathrm{C}$ and $15{ }^{\circ} \mathrm{C}$, respectively (Cao et al., 2013). Briefly, approximately $3 \mathrm{~g}$ of ground material $(<0.84 \mathrm{~mm})$ contained in a cellulose thimble was boiled under reflux in $40 \mathrm{~mL}$ petroleum ether for $15 \mathrm{~min}$. This was followed by continuously rinsing the sample for 120 min under reflux conditions before the petroleum ether was evaporated and the extracted oil was oven-dried at 
$130{ }^{\circ} \mathrm{C}$ for $30 \mathrm{~min}$. The dried oil was allowed to cool in a desiccator for at least $30 \mathrm{~min}$ before extracted oil weight was determined.

\subsection{Protein Content and Molecular Mass Distribution}

The concentration of total $\mathrm{N}$ in each sample was determined using a LECO Truspec dry combustion Carbon/Nitrogen Analyzer. Crude protein content in the samples was calculated by multiplying the total $\mathrm{N}$ by a factor of 6.25 (He et al., 2014f; Proto et al., 2000).

For SDS-polyacrylamide gel electrophoresis (PAGE), product samples were dissolved in $20 \mathrm{mM} \mathrm{NaOH}$ at the concentration $4.3-5.1 \mathrm{mg}$ sample $\mathrm{mL}^{-1}$. These mixtures were centrifuged at $13,000 \mathrm{rpm}$ for $10 \mathrm{~min}$ after sonication for $20 \mathrm{x} 1 \mathrm{sec}$ stokes at power 10. Total proteins in the supernatants were estimated with Coomassie Protein Assay Reagent (ThermoScientific, Waltham, MA, USA) using BSA as standards. About $5 \mu \mathrm{g}$ of total proteins in each sample were separated by SDS-PAGE, using 4-12\% Bis-Tris gel and MES running buffer (Invitrogen, Gaithersburg, MD, USA). The gel was stained with SimplyBlue SafeStain (Invitrogen, Gaithersburg, MD, USA).

\subsection{Statistical Analysis}

Mean values for ash and mineral contents between different meal products were compared using the recommended Ryan's Q (modified) test if variances were equal between means and Games-Howell's test if variances were found unequal between means (Day \& Quinn, 1989). Homogeneity of the variance was determined by the Bartlett's test (Snedecor \& Cochran, 1967).

\section{Results and Discussion}

\subsection{Mass Yield and Protein Recovery}

The mass yield and protein recovery of pilot produced cottonseed meal products is listed in Table 2. Per the procedure, $17.3 \%$ of the starting CSM was recovered as WCSM by mass. The mass yield of CSIR and CSPa was $13.0 \%$ and $3.8 \%$, respectively. The portion of CSPw accounted only for $0.7 \%$ of CSM mass. The low yield of CSPw was partially due to the gyssopol effect as Berardi et al. (1969) observed higher CSPw yield with glandless (without gossypol) cottonseed meal than glanded (with gossypol) meal, even though the CSPw could be extracted with more vigorous blending (He et al., 2013a).

Table 2. Yield and protein recovery of pilot produced cottonseed meal products

\begin{tabular}{rrrrr}
\hline \multicolumn{4}{c}{ Mass yield } & \multicolumn{3}{c}{ Protein recovery } \\
\hline \multicolumn{3}{c}{ Product weight (g) Yield (\%) } & Protein weight (g) & Recovery (\%) \\
\hline $\mathrm{WCSM}$ & $783 \pm 93$ & 17.3 & $362 \pm 37$ & 23.4 \\
$\mathrm{CSIR}$ & $629 \pm 129$ & 13.8 & $220 \pm 47$ & 14.2 \\
$\mathrm{CSPw}$ & $33 \pm 3$ & 0.7 & $21 \pm 1$ & 1.3 \\
$\mathrm{CSPa}$ & $180 \pm 20$ & 3.8 & $182 \pm 18$ & 11.8 \\
$\mathrm{WSF}^{\dagger}$ & $719 \pm 89$ & 15.8 & $127 \pm 16$ & 8.2 \\
$\mathrm{ASF}^{\dagger}$ & $560 \pm 212$ & 12.3 & $253 \pm 96$ & 16.4 \\
Total & $2904 \pm 160$ & 64.0 & $1165 \pm 102$ & 75.3 \\
\hline
\end{tabular}

Notes. ${ }^{\dagger}$ : No product collected. Estimated per sampling analysis.

The solid content in uncollected soluble fractions WSF and ASF accounted for $15.8 \%$ and $12.3 \%$ of the initial sample mass, respectively, resulting in the $64.0 \%$ of total CSM mass recovered with the pilot-scale production trial. The moderate, rather than high, mass recovery was apparently due to the high loss of the mass in the operation with the relative small amount of staring material (10 lb each run). On the other hand, the total recovery of protein of CSM was higher (75.3\%) than the mass recovery. Indeed, the protein recovery was higher than the corresponding mass yield in all fractions, except for water soluble residual fraction WSF $(8.2 \%$ of protein recovery vs. $15.8 \%$ of mass yield). This observation indicated the washing step in the pilot-scale production procedure removed mostly non-protein ingredients. It was noticeable that the protein recovery in $\mathrm{CSPw}$ and CSPa was lower than in their residual fractions of acidic precipitation of CSPw and CSPa, respectively. This observation indicated that the protein precipitation was not completed in the pilot scale trial. One improvement could be the extension of the precipitation time with extra $\mathrm{HCl}$ addition if needed as protein precipitation was a relatively slow process. 


\subsection{Major Components of Pilot Produced Cottonseed Meal Products}

Similar to the staring material WCM, the moisture content was about $8-11 \%$ of these cottonseed meal products (Table 3). Proteins were enriched in WCSM to $46.3 \%$ from $34.1 \%$ in CSM. The alkali-extracted residual fraction CSIR remained a protein content of $34.9 \%$. The protein content of CSPw was $64.4 \%$ which was lower than the protein content of laboratory-made CSPw (He et al., 2013a; He et al., 2015). The product CSPa was basically protein-dominated, more like the total protein isolate CSPI, which is also observed with the laboratory-made CSPa and CSPI (He et al., 2013a; He et al., 2015). Oil was an impurity (2.5\%) in the staring material CSM (Table 1). There was still some oil in these products with the highest content (3.4\%) in CSPw (Table3). Data in Table 3 also shows that fiber was a major component in WCSM and CSIR, but a minor (i.e. impurity) in protein fractions CSPw, CSPa, and CSPI. The contents of ADF, NDF, and ADL were all higher in the pilot-scale produced WCSM and CSIR than the two fractions from laboratory experiments (He et al., 2015) apparently due to the higher fiber content in the mill-produced staring material CSM. Those data also revealed that there were $17.6 \%$ and $8.4 \%$ of WCSM, and $24.6 \%$ and $10.2 \%$ of CSIR, respectively, as cellulose and hemicelluloses.

In addition, the contents of crude fiber (CF) were measured. The content of $\mathrm{CF}$ was $11.7 \%, 16.0 \%$, and $23.5 \%$ in CSM, WCSM and CSIR, respectively (Table 1 and 3), following the same orders of ADF, NDF, and ADL in the three samples. Thus, water washing enriched not only protein component in WCSM and protein fractions CSPw and CSPa, but also fiber and lignin components in WCSM and CSIR. It was notable that the content of CF was lower than ADF and NDF in both WCSM and CSIR. This was because CF measured the organic residues after both alkali and acid digestions so that portions of both the structural carbohydrates and lignin might had also been destroyed. However, content of CF higher than ADF and NDF was reported in cotton hull and burrs (Cheng $\&$ Biswas, 2011) and wheat milling fractions (Saunders \& Hautala, 1979).

\subsection{Ash and Selected Mineral Element Contents}

Contents of ash, six macro elements and seven micro elements of the starting material CSM and the products are listed in Table 4. The ash content was lower in all products than in CSM, suggesting that washing reduced the mineral elements in CSM. The contents of $\mathrm{P}$ and $\mathrm{K}$, the highest two in the six macroelements also decreased in the same order of ash content, suggesting that $\mathrm{P}$ and $\mathrm{K}$ were the major contributors of ash. There was not much difference in the contents of less abundant macroelements $\mathrm{Ca}$ and Mg between WCS and products WCSM as well as CSIR. However, the contents of the divalent metals were lower in the three protein products CSPw, CSPa, and CSPI than CSM. These data indicated that these minerals in the meal and its products should be mainly present in the forms of $\mathrm{K}$ phytate (potassium inositol hexakisphosphate) bonding with $\mathrm{P}$ (i. e. $\mathrm{K}_{12} \mathrm{C}_{6} \mathrm{H}_{6} \mathrm{O}_{24} \mathrm{P}_{6}$ ), with the secondary highest contributions of $\mathrm{Mg}$ and Ca phytate $\left(\mathrm{Mg}_{6} \mathrm{C}_{6} \mathrm{H}_{6} \mathrm{O}_{24} \mathrm{P}_{6}\right.$ and $\mathrm{Ca}_{6} \mathrm{C}_{6} \mathrm{H}_{6} \mathrm{O}_{24} \mathrm{P}_{6}$ ) (Han, 1988; $\mathrm{He}$ et al., 2006, 2013c). The content of Na was lower in water washed product WCSM and CSPw, but higher in alkali-relevant CSIR, CSPa, and CSPa, compared to the starting material CSM. Apparently, the higher content of $\mathrm{Na}$ in CSIR, CSPa and CSPI was introduced in the alkali treatment. Unlike other 5 macroelements, the content of $\mathrm{S}$ was higher in the three protein products CSPw, CSPa, and CSPI than in CSM, WCSM, and CSIR. This observation indicated that the amino acids cysteine (cystine) and/or methionine in protein (He et al., 2014d; Voet \& Voet, 1990) were the major S source in the products. Furthermore, a high S content in CSPw than in CSPa and CSPI was consistent with the previous observation that the content of cysteine of CSPa was the highest among the three lab-produced protein fractions (He et al., 2014f). The contents of the micromineral elements were in the general range of cottonseed and meal products (Bellaloui et al., 2015a; Bellaloui \& Turley, 2013; He et al., 2013b). Similar to those lab-produced products (He et al., 2014f) and due to the nature of micro abundance, the changes of these mineral contents were relatively small, compared to the percentage of the major components and macro elements in the composition of these products. A positive observation was that, without remarkable changes in these micro minerals and other nutrients, CSIR could be used at least as animal feedstuffs as CSM does (Arieli, 1998; Bellaloui et al., 2015b) whereas its industrial utilization need to be explored.

\subsection{Polypeptide Composition of Cottonseed Protein in the Meal and Protein Isolates}

The SDS-PAGE images of CSM, WCSM, CSPw, CSPa, and CSPI are showing in Figure 2. The distribution patterns of the protein subunits of these products were similar to the previous observations with lab-produced CSPw, CSPa, and CSPI with 20 and $100 \mu$ g loaded protein each lane (He et al., 2013a). However, with the less protein loaded $(5 \mu \mathrm{g})$ and a higher resolution in low molecular mass bands, the different polypeptide bands of the cottonseed proteins in Figure 2 was separated better than those in previous work (He et al., 2013a). At least 9 
Table 3. Major components of pilot produced cottonseed meal products

\begin{tabular}{|c|c|c|c|c|c|c|c|c|c|}
\hline & & & Oil & $\mathrm{F}$ & $\mathrm{ADF}$ & NDF & \multicolumn{3}{|c|}{ ADL Cellulose Hemicellulose } \\
\hline \multicolumn{10}{|c|}{ \% of product weight- } \\
\hline & & & & & & & & & $4 \pm 2$ \\
\hline $\mathrm{C}$ & 10.7 & 34.9 & 0.1 & 23. & 38.5 & 6. & 13.9 & & $2 \pm 5.4$ \\
\hline$\overline{\mathrm{CS}}$ & $9 \pm 1.4$ & $64.4=$ & 3.0 & $.9 \pm 0.4$ & 2.5 & \pm 0.5 & $0.9 \pm 0.1$ & 0.3 & $\mathrm{ND}^{*}$ \\
\hline $\mathrm{CSPa}$ & $2 \pm 1.5$ & $101.2 \pm 2$ & \pm 0.1 & $0.1 \pm 0.0$ & $0.3 \pm 0.1$ & ND & ND & $0.3 \pm 0.1$ & ND \\
\hline $\mathrm{CSPI}^{\dagger}$ & $9.6 \pm 0.2$ & $94.8 \pm 1.00$ & \pm 0.1 & $1.0 \pm 0.1$ & $0.7 \pm 0.1$ & $0.1 \pm 0.0$ & $0.1 \pm 0.0$ & $0.6 \pm 0.1$ & ND \\
\hline
\end{tabular}

Notes. ${ }^{\dagger}$ : For comparison only. Produced separately by alkali extraction-acid precipitation with the same batch of the staring material CSM; ${ }^{\star}$. Not detected.

Table 4. Ash and selected mineral element contents in starting material CSM and the products

\begin{tabular}{|c|c|c|c|c|c|c|c|c|c|c|c|c|c|c|}
\hline & $n$ & $\mathrm{P}$ & & $\Lambda$ & & $\mathrm{Na}$ & $\mathrm{s}$ & 10 & $\mathrm{Zn}$ & - & & $\mathrm{N}_{1}$ & Al & \\
\hline \multicolumn{15}{|c|}{ 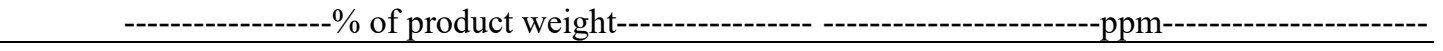 } \\
\hline & 715 & 110 & & & & 024 & 052 & 101 & 77 & 11 & 21 & 1 & 149 & \\
\hline & 0.4 & & & & & & & & & & & & $\mathrm{~b}$ & \\
\hline C & $96 \mathrm{a}$ & 1. & 0.29 & & & & & & & $\beta$ & $49 \mathrm{a}$ & $3 \beta$ & $1 \mathrm{~b}$ & \\
\hline C & $4.64 \mathrm{a}$ & $1.11 \alpha \beta$ & 0.1 & & & & & & c & $\alpha \beta$ & $1 \mathrm{~b}$ & $61 \alpha \beta$ & $313 a$ & \\
\hline & $.25 \mathrm{~b}$ & 33 & $0.07 b c$ & 0.16 & $0.08 \mathrm{bc}$ & 0.2 & $0.60 \mathrm{~b}$ & & $54 \mathrm{~b}$ & $63 \alpha \beta$ & $12 b$ & $\alpha$ & $89 \mathrm{~b}$ & \\
\hline $\mathrm{CSPI}^{*}$ & $2.16 \mathrm{~b}$ & $49 \beta$ & 0.03 & $2 \mathrm{bc}$ & 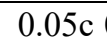 & & $65 \mathrm{~b}$ & $69 \mathrm{~b}$ & $27 \mathrm{c}$ & $60 \alpha$ & 81 & $1.3 \beta$ & 79 & \\
\hline
\end{tabular}

Notes. ${ }^{\dagger}$ : Values with the same letter in the same column are not significantly different at $\alpha=0.05$. Lower case and Greek letters indicate groupings according to Ryan's Q and Games-Howell's tests (28), respectively (Day and Quinn, 1989; Snedecor \& Cochran, 1967); ${ }^{\star}$ : For comparison only. Produced separately by alkali extraction-acid precipitation with the same batch of the staring material CSM.

polypeptide bands ranged from 50 to $6 \mathrm{kDa}$ were present in the gel lane of CSM. A faint band just below $98 \mathrm{kDa}$ was also observed. These bands were also observed in the gel lane of CSPI. Previously, 10 to 13 polypeptide bands were reported in cottonseed protein isolates (King, 1980; Marshall et al., 1984). The band patterns were not changed much in the lanes of WCSM and CSPa, indicating the majority of the cottonseed protein components kept in the two products. On the other hand, more differences in the polypeptide band distribution were observed in the sample of CSPw, characterized by slightly different molecular weights and more bands below $20 \mathrm{kDa}$ (shown by arrows 1-7). The differential banding patterns between CSPw and others were currently unsolved and analysis of these bands by mass spectrometry will uncover their identities. Those observations confirmed the consistence of the protein composition of CSPa, CSPa, and CSPI prepared in the laboratory (He et al., 2013) and pilot trials in this work, and the protein composition of WCSM was similar to that of CSPa.

\section{Conclusions}

In this work, a pilot-scale production of WCSM was evaluated. CSPw was recovered in the water washed solution. Lower protein, but higher fiber contents were observed in the product WCSM, compared to the data of laboratory produced WCSM. These differences were mainly due to the higher fiber content in the starting meal material. Other chemical composition was comparable between the pilot and laboratory produced WCSM. The protein content of CSPw was lower with higher residual oil and ash contents than the laboratory produced CSPw, indicating that additional rinse step should be implemented after CSPw fraction was precipitated by $\mathrm{HCl}$ acidification.

Alternatively, the procedure could be switched to produce CSPw, CSPa, and the residual fraction CSIR. The protein content and purity of CSPa were comparable to CSPa produced in the laboratory scale. However, the yields of both CSPw and CSPa need further improvement for the pilot production. Although the industrial utilization of CSIR has not explored yet the data of its chemical composition suggested that, at least, it could be used as animal feedstuffs as the defatted cottonseed meal itself. 


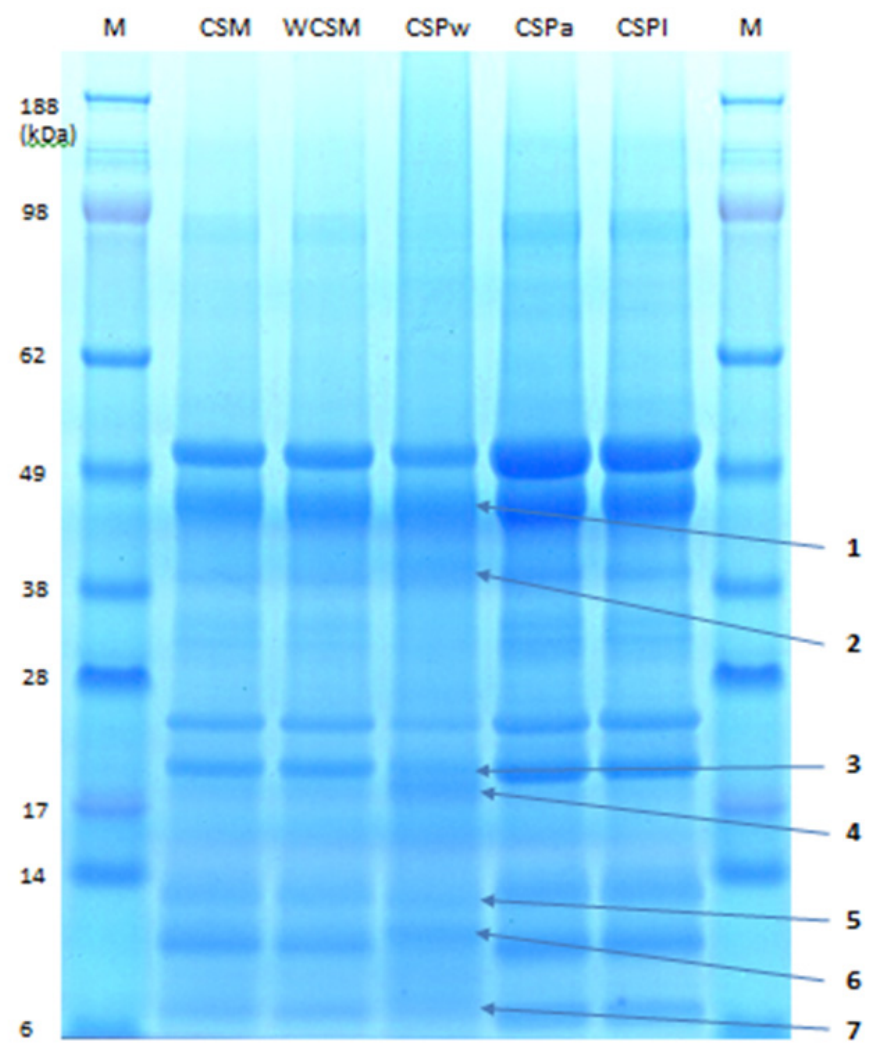

Figure 2. SDS-polyacrylamide gel electrophoresis of the staring material cottonseed meal (CSM), and products WCSM, CSPw, and CSPa, as well as CSPI produced separately by alkali extraction-acid precipitation with the same batch of CSM. Protein bands in CSPw, which were slightly different in molecular weight from other samples were indicated by arrows 1-7. M: molecular weight maker

\section{Acknowledgments}

Mention of trade names or commercial products in this publication is solely for the purpose of providing specific information and does not imply recommendation or endorsement by the U.S. Department of Agriculture. USDA is an equal opportunity provider and employer.

\section{References}

Arieli, A. (1998). Whole cottonseed in dairy cattle feeding: A review. Anim. Feed. Sci. Technol., 72, 97-110.

Bellaloui, N., \& Turley, R. B. (2013). Effects of fuzzless cottonseed phenotype on cottonseed nutrient composition in near isogenic cotton (Gossypium hirsutum L.) mutant lines under well-watered and water stress conditions. Front. Plant Sci., 4, 516. http://dx.doi.org/510.3389/fpls.2013.00516

Bellaloui, N., Stetina, S. R., \& Turley, R. B. (2015a). Cottonseed protein, oil, and mineral status in near-isogenic Gossypium hirsutum cotton lines expressing fuzzy/linted and fuzzless/linted seed phenotypes under field conditions. Front. Plant Sci., 6, 137. http://dx.doi.org/110.3389\%3382Ffpls.2015.00137

Bellaloui, N., Turley, R. B., \& Stetina, S. R. (2015b). Water stress and foliar boron application altered cell wall boron and seed nutrition in near-isogenic cotton lines expressing fuzzy and fuzzless seed phenotypes. PloS one, 10. http://dx.doi.org/10.1371/journal.pone.0130759

Berardi, L. C., Martinez, W. H., \& Fernandez, C. J. (1969). Cottonseed protein isolates: Two step extraction procedure. Food Technol., 23, 75-82.

Bertrand, J. A., Sudduth, T. Q., Condon, A., Jenkins, T. C., \& Calhoun, M. C. (2005). Nutrient content of whole cottonseed. J. Dairy Sci., 88, 1470-1477.

Broderick, G. A., Kerkman, T. M., Sullivan, H. M., Dowd, M. K., \& Funk, P. A. (2013). Effect of replacing 
soybean meal protein with protein from upland cottonseed, Pima cottonseed, or extruded Pima cottonseed on production of lactating dairy cows. J. Dairy Sci., 96, 2374-2386. http://dx.doi.org/10.3168/jds.2012-5723

Campbell, B. T., Boykin, D., Abdo, Z., \& Meredith, W. R. (2014). Cotton. In S. Smith, B. Diers, J. Specht, \& B. Carver (Eds.), Yield Gains in Major U.S. Field Crops (pp. 13-32). American Chemical Society, Madison: WI.

Cao, H., Shockey, J. M., Klasson, K. T., Chapital, D. C., Mason, C. B., \& Scheffler, B. E. (2013). Developmental regulation of diacylglycerol acyltransferase family gene expression in tung tree tissues. PloS one, 8 . http://dx.doi.org/10.1371/journal.pone.0076946

Cheng, H. N., \& Biswas, A. (2011). Chemical modification of cotton-based natural materials: Products from carboxymethylation. Carbohydr. Polymer, 84, 1004-1010. http://dx.doi.org/10.1016/j.carbpol.2010.12.059

Cheng, H. N., Dowd, M. K., \& He, Z. (2013). Investigation of modified cottonseed protein adhesives for wood composites. Ind. Crop. Prod., 46, 399-403. http://dx.doi.org/10.1016/j.indcrop.2013.02.021

Day, R. W., \& Quinn, G. P. (1989). Comparisons of treatments after an analysis of variance in ecology. Ecolog. Monogr., 59, 433-463.

Han, Y. W. (1988). Removal of phytic acid from soybean and cottonseed meals. J. Agric. Food Chem., 36, 1181-1183.

He, Z., Cao, H., Cheng, H. N., Zou, H., \& Hunt, J. F. (2013a). Effects of vigorous blending on yield and quality of protein isolates extracted from cottonseed and soy flours. Modern Appl. Sci., 7(10), 79-88. http://dx.doi.org/10.5539/mas.v7n10p79

He, Z., Chapital, D. C., Cheng, H. N., \& Dowd, M. K. (2014a). Comparison of adhesive properties of water-and phosphate buffer-washed cottonseed meals with cottonseed protein isolate on maple and poplar veneers. Int. J. Adhes. Adhes., 50, 102-106. http://dx.doi.org/10.1016/j.ijadhadh.2014.01.019

He, Z., Chapital, D. C., Cheng, H. N., Klasson, K. T., Olanya, M. O., \& Uknalis, J. (2014b). Application of tung oil to improve adhesion strength and water resistance of cottonseed meal and protein adhesives on maple veneer. Ind. Crop. Prod., 61, 398-402. http://dx.doi.org/10.1016/j.indcrop.2014.07.031

He, Z., Cheng, H. N., Chapital, D. C., \& Dowd, M. K. (2014c). Sequential fractionation of cottonseed meal to improve its wood adhesive properties. J. Am. Oil Chem. Soc., 91, 151-158. http://dx.doi.org/10.1007/s11746-013-2349-2

He, Z., Honeycutt, C. W., Zhang, T., \& Bertsch, P. M. (2006). Preparation and FT-IR characterization of metal phytate compounds. J. Environ. Qual., 35, 1319-1328. http://dx.doi.org/10.2134/jeq2006.0008

He, Z., Olk, D. C., \& Waldrip, H. M. (2014d). Soil amino compound and carbohydrate contents influenced by organic amendments. In Z. He, \& H. Zhang (Eds.), Applied Manure and Nutrient Chemistry for Sustainable Agriculture and Environment (pp. 69-82). http://dx.doi.org/10.1007/978-94-017-8807-6_4

He, Z., Shankle, M., Zhang, H., Way, T. R., Tewolde, H., \& Uchimiya, M. (2013b). Mineral composition of cottonseed is affected by fertilization management practices. Agron. J., 105, 341-350. http://dx.doi.org/10.2134/agronj2012.0351

He, Z., Uchimiya, M., \& Cao, H. (2014e). Intrinsic fluorescence excitation-emission matrix spectral features of cottonseed protein fractions and the effects of denaturants. J. Am. Oil Chem. Soc., 91, 1489-1497. http://dx.doi.org/10.1007/s11746-014-2495-1

He, Z., Zhang, H., \& Olk, D. C. (2015). Chemical composition of defatted cottonseed and soy meal products. PLoS One, 10(6). http://dx.doi.org/0129910.0121371/journal.pone.0129933

He, Z., Zhang, H., Olk, D. C., Shankle, M., Way, T. R., \& Tewolde, H. (2014f). Protein and fiber profiles of cottonseed from upland cotton with different fertilizations. Modern Appl. Sci., 8(4), 97-105. http://dx.doi.org/10.5539/mas.v8n4p97

He, Z., Zhong, J., \& Cheng, H. N. (2013c). Conformational change of metal phytates: solid state 1D 13C and 2D 1H-13C NMR spectroscopic investigations. J. Food Agri. Environ., 11(1), 965-970.

King, E. E. (1980). Compositional relationships among electrophoretic isolates from cottonseed protein bodies. Phytochem, 19, 1647-1651.

Li, J., Li, D., Zang, J., Yang, W., Zhang, W., \& Zhang, L. (2012). Evaluation of energy digestibility and prediction of digestible and metabolizable energy from chemical composition of different cottonseed meal 
sources fed to growing pigs. Asian-Aust. J. Anim. Sci., 25, 1430-1438. http://dx.doi.org/10.5713/ajas.2012.12201

Marshall, H. F., Shirer, M. A., \& Cherry, J. P. (1984). Characterization of glandless cottonseed storage proteins by sodium dodecyl sulfate-polyacrylamide gel electrophoresis. Cereal Chem., 61, 166-169.

Nida, D. L., Patzer, S., Harvey, P., Stipoanovic, R., Wood, R., \& Fuchs, R. L. (1996). Glyphosate-tolerant cotton: the composition of the cottonseed is equivalent to that of conventional cottonseed. J. Agric. Food Chem., 44, 1967-1974.

Pettigrew, W. T., \& Dowd, M. K. (2014). Nitrogen fertility and irrigation effects on cottonseed composition. $J$. Cotton Sci., 18, 410-419.

Proto, M., Supino, S., \& Malandrino, O. (2000). Cotton: a flow cycle to exploit. Ind. Crop. Prod., 11, $173-178$.

Saunders, R. M., \& Hautala, E. (1979). Relationships among crude fiber, neutral detergent fiber, in vitro dietary fiber, and in vivo (rats) dietary fiber in wheat foods. Am. J. Clin. Nutr., 32, 1189-1191.

Snedecor, G. W., \& Cochran, W. G. (1967). Statistical Methods. 6th ed. The Iowa State University Press, Ames, IA, 296-298.

Tazisong, I. A., He, Z., \& Senwo, Z. N. (2013). Inorganic and enzymatically hydrolyzable organic phosphorus of Alabama Decatur silt loam soils cropped with upland cotton. Soil Sci., 178, 231-239. http://dx.doi.org/ $10.1097 /$ SS.0b013e31829cf464

Voet, D., \& Voet, J. (1990). Chapter 4. Amino acids. In Biochemistry. John Wiley \& Son, Inc., New York, N.Y., 59-74.

Wanapat, M., Anantasook, N., Rowlinson, P., Pilajun, R., \& Gunun, P. (2013). Effect of carbohydrate sources and levels of cotton seed meal in concentrate on feed intake, nutrient digestibility, rumen fermentation and microbial protein synthesis in young dairy bulls. Asian-Aus. J. Anim. Sci., 26, 529-536. http://dx.doi.org/10.5713/ajas.2012.12607

Wolfrum, E. J., Lorenz, A. J., \& deLeon, N. (2009). Correlating detergent fiber analysis and dietary fiber analysis data for corn stover collected by NIRS. Cellulose, 16, 577-585. http://dx.doi.org/10.1007/s10570-009-9318-9

Yue, H. B., Cui, Y. D., Shuttleworth, P. S., \& Clark, J. H. (2012). Preparation and characterization of bioplastics made from cottonseed protein. Green Chem., 14, 2009-2016. http://dx.doi.org/10.1039/c2gc35509d

Zhang, B., Cui, Y., Yin, G., Li, X., \& You, Y. (2010). Synthesis and swelling properties of hydrolyzed cottonseed protein composite superabsorbent hydrogel. Int. J. Polym. Mat. Polym. Biomat., 59, 1018-1032. http://dx.doi.org/10.1080/00914031003760709

Zhang, B., Cui, Y., Yin, G., Li, X., \& Zhou, X. (2009). Alkaline extraction method of cottonseed protein isolate. Modern Appl. Sci., 3(3), 77-82.

\section{Copyrights}

Copyright for this article is retained by the author(s), with first publication rights granted to the journal.

This is an open-access article distributed under the terms and conditions of the Creative Commons Attribution license (http://creativecommons.org/licenses/by/3.0/). 